\title{
DELIK PENCEMARAN NAMA BAIK YANG DILAKUKAN OLEH ADVOKAT DALAM MELAKSANAKAN TUGASNYA SEBAGAI KUASA KLIEN
}

\author{
Mohamad Adnan Fanani \\ adnanfanani18@gmail.com \\ Universitas Airlangga
}

\begin{abstract}
Everyone has a sense of self-respect about respect and self-respect about good name. The criminal act of humiliation (beleediging) formed by the legislators, both general and special, is intended to provide protection for the legal inerest regarding this feeling. Regarding criminal acts of humiliation (defamation), there are those that are general insults and there are special insults regulated in the Criminal Code. This journal uses normative research methods by examining the legal arrangements regarding criminal defamation. The data source used in this thesis is secondary data and is classified on primary legal material consisting of the Criminal Code, Law Number 18 of 2003 concerning Advocates and secondary legal material consisting of books and legislation relating to criminal liability in the case of a letter indicating the existence of a defamation offense committed by an advocate in carrying out his duties as the client's authority. Because this research is a normative research, the data collection method used is the study of the Statute Approach and Conceptual Approach. Data analysis used in this study uses qualitative data analysis. With this writing, it is hoped that it can be useful and increase knowledge for its readers.
\end{abstract}

Keywords: Defamation; Advocates; Clients.

\begin{abstract}
Abstrak
Setiap orang memiliki rasa harga diri mengenai kehormatan dan rasa harga diri mengenai nama baik. Tindak pidana penghinaan (beleediging) yang dibentuk oleh pembentuk undang-undang, baik yang bersifat umum, maupun yang bersifat khusus, ditujukan untuk memberi perlindungan bagi kepentingan hukum mengenai rasa semacam ini. Tentang tindak pidana penghinaan (pencemaran nama baik), ada yang merupakan penghinaan umum dan ada penghinaan khusus yang diatur dalam KUHP. Jurnal ini menggunakan metode penelitian normatif dengan mengkaji pengaturan hukum mengenai tindak pidana pencemaran nama baik. Sumber data yang digunakan dalam tesis ini adalah data sekunder dan digolongkan atas bahan hukum primer yang terdiri dari KUHP, Undang-Undang Nomor 18 Tahun 2003 Tentang Advokat dan UU No. 11 Tahun 2008 tentang Informasi dan Transaksi Elektronik, bahan hukum sekunder yang terdiri dari buku - buku dan peraturan perundang-undangan yang berhubungan dengan pertanggungjawaban pidana dalam hal surat yang berindikasi adanya delik pencemaran nama baik yang dilakukan oleh advokat dalam melaksanakan tugasnya sebagai kuasa klien. Dikarenakan penelitian ini merupakan penelitian normatif maka metode pengumpulan data yang digunakan adalah dengan studi Pendekatan Perundang-Undang an (Statute Approach) dan pendekatan konseptual ( Conceptual Approach). Analisis data yang digunakan dalam penelitian ini menggunakan analisis data kualitatif. Dengan penulisan ini diharapakan dapat bermanfaat dan menambah pengetahuan bagi para pembacanya.
\end{abstract}

Kata Kunci: Pencemaran nama baik; Advokat; Klien.

\section{Pendahuluan}

Pengertian advokat sendiri adalah seorang yang dapat membatu atau 
memberikan pendampingan dalam bentuk jasa bantuan masalah hokum dalam pengekan hukumyang mengahadapi masalah hokum yang kedudukannya di butuhkan pada masyarakat.peran yang dimilik advokat sendiri,yaitu kewajiban dan bertanggungjawab atas klienya dimana ia di tunjuk untuk mendampingi dalam tindak pidana yang melanggar hukum.

Sumpahnya advokat sendiri, dalam menjalankan tugasnya akan menjunjung kebenaran atau tidak akan bebuat palsu meskipun itu berhubungan di dalam atau di laur pengadilan.serta dokumen-dokumen yang di butuhkan dalam proses tindak pidana semua surat-suratnya asli seperti gugatan atau tuntutan yang berdasarkan hokum. Hal ini karena advokat harus menjujung kode etika advokat, dimana dalam menjalankan tugasnya ia harus mematuhinya untuk membela atau mendampingi kliennya dalam persidangan atau proses hokum yang berlaku.

Hak dan kewajiba advokat sendiri dalam menjalankan perannya harus sesuai. Hal itu sendiri sesuai dengan Kode Etika Advokat Indonesia dan Undang-Undang Nomor 18 Tahun 2003 tentang Advokat. Hubungan atara advokat dan kliennya di pandang dari advokat sebagi officer of the court, yang mempunyai dua konsekuensi yuridis, sebagai berikut:

1. Pengedilan akan memantau bahkan memaksakan agar advokat selalu tunduk pada ketentuan Undang-Undang atau berperilaku yang patut dan pantas terhadap kliennya.

2. Karena advokat harus membela kliennya semaksimal mungkin, maka advokat harus hati-hati dan tunduk sepenuhnya kepada aturan hokum yang berlaku.

Advokat sendiri tidak boleh melanggar aturan hokum yang berlaku dalam membela kliennya, sekaligus memetingkan orang lain yang bukan kilennya. Karena ia di tunjuk sebagai jasa hokum pemberi nasehat atau pembelaan hukum kepada kliennya dengan kata lain sebagai moderator kepeda yang bersengketa suatu perkara baik itu perkara pidana,perdata, atau tata usaha Negara. Advokat sendiri mejalankan kuasa, mendampingi dan melakukan tindakan hokum guna untuk kepetingan klien yang di lakukan baik di dalm pengadilan maupun luar pengadilan yang sesuai dengan kode etik advokat sendiri dan berhubungan dengan pekerjaanya 
yang berdasarkan ketentuan UU advokat no 18 tahun 2003.

Delik pencemaan nama baik, objek yang ingin di lindungi adalah kewajiban setiap orang untuk menghormati orang lain dari sudut kehormatannnya dan nama baiknya dimata orang lain meskipun orang tersebut telah melakukan kejahatn yang berat. Kriminalisasi atas perbuatan pencemaran nama baik, penghinaan, hasutan, dan menyebarkan kabar bohong merupakan upaya Negara melakukan perlindungan terhadap reputasi atau nama baik orang maupun lembaga. ${ }^{1}$

Salah satu kasus yang terjadi akhir-akhir ini di lingkunagn kita adalah pencemaran nama baik. Kasus ini biasanya terjadi di lingkungan masyarakat, dalam hal ini kemajuan dan kecanggihan teknologi sangat berperan besar dalam mendukung terjadinya kasus pencemaran nama baik. Delik pencemaran nama baik bersifat subjektif, yaitu penilaian terhadap pencemaran nama baik tergantung pada pihak yang diserang nama baiknya. Pencemaran nama baik melalui media elektronik di atur Undang-Undang Nomor 11 tahun 2008 tentang Informasi dan Transaksi Elektronik Psal 27 ayat (3).

Begitu mudah wartawan atau media dilaporkan ke polisi dengan tuduhan pencemaran nama baik atau penghinaan. Dalam UU ITE, ketentuan penghinaan dan pencemaran nama baik di atur dalam pasal 27 ayat (3) untuk menentukan adanya penghinaan atau pencemaran nama baik, konten dan konteks menjadi bagian yang sangat penting untuk di pahami.

Kasus delik pencemaran nama baik yang dilakukan advokat adalah kasus Sutarjo, SH, MH dan Sudarmono, SH, dua advokat anggota Peradi Sidoarjo tengah berusaha memperjuangkan nasibnya di Pengadilan Negeri Surabaya. Kedua advokat itu ditetapkan sebagai tersangka Polda Jatim atas kasus fitnah berdasarkan laporan notaries Mashudi, SH., Mkn. Mashudi merasa tidak terima karena Sutarjo dan Sudarmono telah melaporkannya ke Majelis Pengawas Daerah Notaris Gresik atas pelanggaran kode etik notaries terkait jual beli tanah. Meskipun keduanya

\footnotetext{
1 Galih Ian, R.,Tinjauan Atas pemberitaan yang Berindikasi Adanya Delik Pencemaran Nama Baik Oleh Media Massa dalam Perpektif Kode Etika Jurnalistik dan UU Pers,(2009) vol 1 Jurnal univeritas jember.
} 
hanya menjalankan profesinya sebagai advokat, Polda Jatim tetap menetapkan sutarjo dan sudarmono sebagai tersangka. Sedangkan dalam Undang- Undang No 18 Tahun 2003 tentang Advokat dan Putusan Mahkamah Konstitusi No 26/ PUU-XI/2013 dalam tugasnya terdakwah harus mendapatkan perlindungan hukum, bahwa terdakwah seorang pemberi jasa hokum yang sedang betugas untuk membela kilennya dan sudah di berikan kuasanya.

Kasus pencemaran nama baik atau penghinaan sendiri harus ada kehatihatian dari kita sebagai advokat karena bias sewaktu-waktu terulang mengenai diri kita dengan kasus serupa. Karena telah terbangun satu persepsi bahwa membuat dan mengajukan surat pengaduan ataupun sejenis termasuk surat somasi bias di anggap sebagai pencemaran nama baik dalam pasal 311 yang menayatakan pasal 310 (1)" Barang siapa sengaja menyerang kehormatan atas nama baik seseorang dengan menuduhkan sesuatu hal itu diketrahui umum, dikecam karena pencemaran nama dengan pidana penjara paling lama Sembilan bulan atau pidana denda paling banyak empat ribu lima ratus rupiah". Untuk menghindari kesewenagna-wenagan bila terjadi anjurkan agar para terdakwah langsung menyatakan banding di depan majelis bahwa menilai pertimbangan tersebut telah mebarak Undang-Undang 18 Tahun 2003 tentang Advokat.

Berdasarkan uaraian di atas, penulis ingin melakukan penelitian terhadap hal tersebut yang kemudian akan di tuangkan dalam bentuk tesis yang berjudul Delik Pencemaran Nama Baik Yang Dilakukan Oleh Advokat Dalam Melaksanakan Tugasnya Sebagai Kuasa Klien.

\section{Pencemaran Nama Baik}

Perbuatan yang mengadu secara mefitnah,menghina baik itu secara ringan termasuk perbuatan pencemaran nama baik karena perbuatan secara sengaja itu dilakukan secara menuduh baik secara lisan atau tulisan. Pencemaran nama baik sendiri bukanlah dianggap sesuatu yang baru. Di era yang semakin majumasi dan komunikasi memiliki sifat eskalatif dimana teknologi informasi ini persaingan sendiri semakin ketat sehingga banyak orang berfikir dengan berbagai cara untuk 
menyaingi lawannya sehingga pencemaran nama baik terdapat aturanya dalam KUHP dan UU ITE. Pencemaran nama baik secara sengaja diartikan dimana pelaku mengetahui perbuatan yang mengitimdasi korban.

Pencemaran nama baik yang oleh undang-undang diberi kualifikasi pencemaran atau penistaan (smaad) dan pencemaran tertulis (smaadschrifft) dirumuskan selengkapnya di dalam Pasal 310 KUHP, yakni: (1) Barang siapa sengaja menyerang kehormatan atau nama baik seseorang dengan menuduhkan sesuatu hal, yang maksudnya terang supaya hal itu diketahui umum, diancam karena pencemaran dengan pidana penjara paling lama sembilan bulan atau pidana denda paling banyak empat ribu lima ratus rupiah. (2) Jika hal itu dilakukan dengan tulisan atau gambaran yang disiarkan, dipertunjukkan atau ditempelkan di muka umum, maka diancam karena pencemaran tertulis dengan pidana penjara paling lama satu tahun empat bulan atau pidana denda paling banyak empat ribu lima ratus rupiah. (3) Tidak merupakan pencemaran atau pencemaran tertulis, jika perbuatan jelas dilakukan demi kepentingan umum atau karena terpaksa untuk membela diri.

Tercemarnya nama baik seseorang secara hakiki yang dapatr di nilai oleh orang yang bersangkutan. Dengan kata lain, korbanlah yang dapat menilai secara subjektif tentang konten atau bagian mana dari informasi dan dokumen elektronik yang ia rasa telah menyerang kehoramtan atas nama baiknya. ${ }^{2}$

\section{Advokat atau pengacara}

Dalam Undang-Undang Nomor 18 Tahun 2003 Tentang Advokat, ${ }^{3}$ yang di maksut dengan advokat adalah orang yang berprofesi memberi jasa hokum, baik di dalam di luar pengdilan yang memenuhi persayaratan berdasarkan ketentuan Undang-Undang ini. Isrilah pembelaan dalamperkara hokum yang sering dipakai adalah pengecara tau advokat.

Pengertian berprofesi sebagai advokat : (sesuai UU 18 tahun 2003) Pasal 1 (1) Ketentuan Umum Advokat dalaha : orang yang berprofesi memberi jasa hokum, baik

\footnotetext{
${ }^{2}$ Oemar Seno Adji, Perkembangan Delik Pers di Indonesia (Erlangga1990).[36].

3 Ibid.[34].
} 
didalam maupun di laur pengadilan yang memenuhi persayartan berdasarkan umum. Pasal 2 (2) Jasa Hukum adalah : jasa yang diberikan advokat berupa memberikan konsultasi hokum, bantuan hokum, menjalankan kuasa, mewakili, mendampingi membela dan melakukan tindakan hokum lain untuk kepentingan hokum klien.

\section{Tindak Pidana}

Tindak pidana meruapak suatu tindakan yang dianggap menyalahi atau melanggar suatu aturan hokum. Istlah belanda sendiri merupakan terjemaahan dari bahasa Belanda "STRAFBAAR FEIT" yang dalam bahasa inggris dari kata Criminal Act. ${ }^{4}$

1. Pandangan yang monistis, yang menyatakan bahwa dalam "STRAFBAAR FEIT" didalamnya terkandung " perbuatan pidana" dan "pertanggungjawaban pidana" sekaligus ( sarjanannya ; Simons, Van Hamel);

2. Pandangan yang dualism, yang menyatakan bahwa dalam "STRAFBAAR FEIT" harus dibedakan atau dipisahkan antara “ perbuatan pidana” dan “pertanggungjawaban” sekaligus ( Sarjannya: Moelyatno, Roeslan Saleh). Saya setuju dengan pendapat yang kedua ini yaitu pandangan dualisme.

\section{Pertanggungjawaban Pidana}

Pertanggungjawaban pidana adalah bukti dari pelaku yang berbuat tindak pidana atau kesalahan yang dilakukannya dengan melawan hukum. Pertanggungjwaban terjadi karena ada kesalahan tindak pidana. Pertanggungjawban pidana sendiri dianggap perbuatan yang tercela di masyarakat dan itu harusdieprtanggungjwabakan oleh si pembuat kesalahannya yang bertujuan agar memberi rasa jera atas tindakan pidananya. Dengan adanya pertanggungjawban pidana dengan menegakkan norma hokum atas konflik atau pidana yang di lakukan di masyarakat dapat menciptakaan rasa damai.

Kesalahan dalam tidak pidana sendiri ada dua jenisnya baik itu dilakukan dengan kesengajaan dan kelalaian. Aapabila kesalahan dengan di sengaja, maka

4 Didik Endro Purwoleksono, hukum pidana (Airlangga University Press 2013).[43]. 
si pelaku dapat dikenakan hokum pidana. Sedangakan kesalahan karna kelalaian dapat dikenaknan tindak pidana lebih ringan. Seseorang yang di kenakan pidana hanya akan dipidana jika memang terbukti dengan sah melakukan dan menyakini kesalahannya sehingga di mintai mempertanggungjwabkan perbuatannnya.

Pasal 16 itu berbunyi” Advokat tidak dapat dituntut baik secara perdata maupun pidana dalam menjalankan tugas profesinya dengan itikad baik untuk kepetingan pembelaan klien dalanm siding pengadilan'. Namun, lebih lanjut lagi, dalam penjelasan memang disebutrkan bahwa" uyang dimaksud dengan "itikad baik" adalah menjalankan tugas profesi demi tegaknya keadailan berdasrkan hokum untuk membela kepentingan kliennya”. Dengan demikina, betul bahwa advokat tidak dapat di tuntut, baik secara perdata maupun secara pidana, namun 'kjekebalan “ itu dimilikinya selama dia menjalankan profesinya berdasarkan hokum. Pasal 15 UU No. 18/2013 Pasal ini persisnya berbunyi: “Advokat bebas dalam menjalankan tugas profesinya untuk membela perkara yang menjadi tanggung jawabnya dengan tetap berpegang pada kode etik profesi dan peraturan perundang-undangan”.

\section{Delik Pencemaran Nama Baik Yang Dilakukan Oleh Advokat Dalam Melaksanakan Tugasnya Sebagai Kuasa Klien}

Indonesia, delik pencemaran nama baik masuk dalak katagori delik pidana formal. System penegak hokum masing-masing mempnyai tugas dan wewenang antara polisi sebagai penyidik, jaksa sebagai penuntut dan hakim bertugas sebagiai yang memutuskan sebuah perkara, sedangkan advokat bertugas sebagai pemihak pada masyarakat dengan membela dan member bantuan hokum untuk mendapatkan keadilan yang seadil-adilnya sesiau dengan kode etik profesi advokat. Hubungan advokat dengan klien sendiri harus mementingkan kepetingan klien daripada kepetingan pribadinya.hubungan ini sendiri tentu saja berkaitan dengan pekerjaan advokat yang sebagai penesehat hokum pada kliennya. Dalam bukunya Kitab Undang-Undang Hukum Pidana (KUHP) serta Komentar-Komentarnya Lengkap Pasal Demi Pasal (1991), berdasarkan ketentuan yang ada di dalam KUHP, ada enam macam penghinaan, yakni: 
a. Menista/smaad (pasal $310 \mathrm{KUHP}$ )

b. Menista Dengan Tulisan/smaadschrift ( Pasal 310 ayat (2))

Pemberian jasa hukum yang dilakukan oleh Advokat kepada masyarakat atau kliennya, dalam hukum positif Indonesia telah diatur secara jelas dan tegas melalui Undang-Undang Republik Indonesia Nomor 18 Tahun 2003 tentang Advokat. Landasan kerja Advokat sampai saat ini hanya menggunakan UndangUndang Republik Indonesia Nomor 18 Tahun 2003 tentang Advokat dan Kode Etik Profesi Advokat sebagai tatanan dalam menertibkan kerja mereka sendiri melalui berbagai Organisasi Advokat.

Advokat bertugas sebagai pemihak pada masyarakat dengan membela dan member bantuan hokum untuk mendapatkan keadilan yang seadil-adilnya sesiau dengan kode etik profesi advokat. Hubungan advokat dengan klien sendiri harus mementingkan kepetingan klien daripada kepetingan pribadinya.hubungan ini sendiri tentu saja berkaitan dengan pekerjaan advokat yang sebagai penesehat hokum pada kliennya. ${ }^{5}$

Unsur- unsur delik sendiri bias terpenuhi tuntutanya karena adanya tindakan suatu pidana. Hal ini menjelaskan bukan semua tindak pidana dapat di tuntut tanpa adanya suatu laporan pengaduan dari seseorang yang menjadi korban tindak pidana itu sendiri. Laporan pengaduan ini sebagai pemberitahuan saja karena syarat bagi korban penuntut adalah pengaduan sendiri. KUHP sendiri mengatur tentang azas hokum pidana tentang pencamaran nama baik.

\section{Pertanggungjawaban Pidana Terhadap Advokat Dalam Pencemaran Nama Baik Pada Saat Mendampingi Kliennya.}

Pertanggungjawaban pidana adalah bukti dari pelaku yang berbuat tindak pidana atau kesalahan yang dilakukannya dengan melawan hukum. Pertanggungjwaban terjadi karena ada kesalahan tindak pidana. Pertanggungjawban pidana sendiri dianggap perbuatan yang tercela di masyarakat dan itu harusdieprtanggungjwabakan oleh si

\footnotetext{
5 T Yosep parera, advokat dan penegak hokum (genta press Yogyakarta 2006).[4].
} 
pembuat kesalahannya yang bertujuan agar memberi rasa jera atas tindakan pidananya. Dengan adanya pertanggungjawban pidana dengan menegakkan norma hokum atas konflik atau pidana yang di lakukan di masyarakat dapat menciptakaan rasa damai.

\section{Azas-azas Pertanggungjawaban Pidana}

Dalam azas-azas pidana sendiri harus di dasari denganpertanggungjawaban pidana, dan isi dari azas-azas tersebut adalah sebagai berikut:

1. Culpability dan Absolute Liability

2. Tanggungjawab Individual dan Kolektif

\section{Unsur-unsur Dalam Pertanggungjawaban Pidana}

Pertanggungjawaban pidana adalah bukti dari pelaku yang berbuat tindak pidana atau kesalahan yang dilakukannya dengan melawan hukum. Pertanggungjwaban terjadi karena ada kesalahan tindak pidana. Pertanggungjawban pidana sendiri dianggap perbuatan yang tercela di masyarakat dan itu harusdieprtanggungjwabakan oleh si pembuat kesalahannya yang bertujuan agar memberi rasa jera atas tindakan pidananya. Dengan adanya pertanggungjawban pidana dengan menegakkan norma hokum atas konflik atau pidana yang di lakukan di masyarakat dapat menciptakaan rasa damai.

Menurut Ruslan Saleh, tidak ada gunanya untuk mempertanggungjawabkan terdakwah atas perbuatanya apabila perbutan itu sendiri tidak bersifat melawan hokum, maka lebih lanjut dapat pula dikatakan bahwa terlebih dahulu harus ada kepastian tentang adanya perbuatan pidana, dan kemudian semua unsur-unsur kesalahan harus dihubungkan pula dengan perbuatan pidana yang dilakukan, sehingga untuk adanya kesalahan yang mengakibatkan dipidanannya terdakwa maka terdakwa haruslah: ${ }^{6}$

a) Melakukan perbuatan pidana;

b) Mampu bertanggung jawab;

c) Dengan kesengajaan atau kealpaan; dan

d) Tidak adanya alasan pemaaf.

\footnotetext{
6 Ibid. [94].
} 


\section{Pertanggungjawaban pidana terhadap advokat dalam pencemaran nama baik pada saat mendampingi kliennya}

Maraknya kasus tentang tudingan delik pencemaran nama baik akhir- akhir ini yang menjadi akibatnya dengan berkembangnya jaman di teknologi dan informatika seperti internet dengan berbagai media social. Sehingga dengan mudah dan cepat sesorang dapat melakukan pencemaran nama baik. Jika seseorang itu memeng terbukti bersalah maka wajib untuk mempertanggungjawabkan perbuatannya.

Dilihat dari KUHP pencemaran nama baik diistilahkan sebagai penghinaan atau penistaan terhadap seseorang. Penghinaan itu harus dilakukan dengan cara menuduh seseorang telah melakukan perbuatan yang tertentu dengan maksud tuduhan itu akan tersiar (diketahui orang banyak). ${ }^{7}$

Sebagai contoh kasus atas pencemaran nama baik yang di lakukan oleh Advokat, Sutarjo SH dan Sudarmono, SH. Perlu diketahui,perkara ini bermula dari surat pengaduan ke MPD Gresik atas Akte No 3 Notaris Mashudi, SH MKn tanggal 18 Mei 2009 oleh terdakwa Sutarjo dan Sudarmono SH. Terdakwa mendapat kuasa dari Khoyana untuk membuat dan mengirim surat pengaduan atas dugaan pelanggaran etik yang dilakukan oleh Notaris dalam pembuatan akte.

Dugaan pelanggaran etik itu adalah pada waktu pembuatan Akte tidak dibacakan, para pihak tidak menghadap dan tidak ada bukti pembayaran lunas oleh pembeli. Notaris tidak terima atas pengaduan tersebut dan lalu melaporkan Terdakwa di Polda Jatim hingga berlanjut dipersidangan ini. Oleh JPU terdakwa dijerat pasal 263 KUHP pemalsuan surat, pencemaran nama baik dengan surat pasal 311KUHP dan pengaduan fitnah kepada penguasa pasal 317 KUHP. Pada Surat tuntutan jaksa hanya menuntut untuk pelanggaran pasal $263 \mathrm{KUH}$ tentang pemalsuan.

Melihat penyelesaian kasus Sutarjo dan Sudarmono SH yang menuai banyak kontroversi itulah maka penulis ingin mengkaji pertanggungjawaban kejahatan pencemaran nama baik pada yang di lakukan advokat dalam mendampingi klien. Pertanggungjwaban terjadi karena ada kesalahan tindak pidana. Pertanggungjawban

\footnotetext{
7 R. Soesilo, Kitab Undang-Undang Hukum Pidana (KUHP) Serta Komentar-Komentarnya Lengkap Pasal Demi Pasal, (Politeia Bogor 1995).[226].
} 
pidana sendiri dianggap perbuatan yang tercela di masyarakat dan itu harusdieprtanggungjwabakan oleh si pembuat kesalahannya yang bertujuan agar memberi rasa jera atas tindakan pidananya.

Sidang kasus pemalsuan surat dengan terdakwa Advokat, Sutarjo SH dan Sudarmono, SH kembali dilanjutkan di ruang Candra PN Surabaya, pada hari rabu 6 september 2016. Dalam sidang yang dipimpin majelis hakim Jihad Arkhanuddin mengagendakan pledoi (pembelaan) dari tim kuasa hukum terdakwa.

Sidang lanjutan advokad Sutarjo dan Sudarmono kian hari kian memanas. Bagaimana tidak, persidangan yang menghadirkan saksi ahli dalam kasus dua advokad pada 17 mei 2017 di penuhi oleh advokad sebagai kuasa hukum dari berbagai organisasi advokad dan wartawan yang meliput. Acara sidang ini berlangsung lama karena saksi yang di hadirkan kali ini saksi ahli seorang Dosen yang di datangkan dari UBHARA yang 30 tahun mengajar bidang mata kuliah Ilmu Hukum pidana. Dr. Solehudin selaku saksi ahli mengemukakan "bahwa tidak ada hak imunitas bagi advokat dan penegak-penegak hukum lainnya terhadap pidana dimana perbuatan seseorang memenuhi unsur delik materil dan unsur pelanggaran terhadap substansi yang ada maka ia sudah termasuk pelanggaran pidana dan sesuai menjadi terdakwa.

Dalam pembelaannya tim kuasa hukum terdakwa menyatakan inti dari nota pembelaan ini adalah untuk menunjukkan dan membuktikan bahwa terdakwa sebagai Advokat yang sedang menjalankan profesinya dengan mendapat kuasa dari kliennya harus mendapatkan perlindungan hukum sesuai amanat UU No 18 Tahun 2003 tentang Advokat dan putusan Mahkamah Konstitusi No. 26/PUU-XI/2013, juga untuk menunjukkan bahwa Jaksa Penuntut Umum (JPU) dapat mengajukan tuntuan hukum.

Pasal 16 UU No. 18/2003 tentang Advokat, hak imunitas advokat yang dimaksud Pasal 16 meliputi tindak-tanduk advokat baik di dalam dan di luar pengadilan. advokat berhak atas kekebalan dari tuntutan hukum, selama hal itu masih dalam konteks menjalankan profesi dan didasari pada itikad baik. Itu pasal dalam satu rangkaian, satu kesatuan. Artinya kalau benar-benar dilakoni dengan itikad baik, walaupun diluar pengadilan itu harus dilindungi, karena kalau tidak 
dia tidak bebas melakukan tugasnya. Sebagai landasan podoman Advokat dalam menangani kasus. Mahkamah Konstitusi (MK) mengabulkan permohonan perkara 26/PUU-XI/2013, pengujian Pasal 16 Undang-Undang (UU) Nomor 18 Tahun 2003 tentang Advokat yang terkenal sebagai hak imunitas advokat yang diajukan oleh sejumlah advokat.

Pertanggungjawaban tindak pidana terjadi karena adanya perbuatan yang melanggar hokum di dalamnya. Sekalipun itu advokat atau seseorang yang berkerja sebagai penegak hokum harus juga mempertanggungjawabkannya jika terbukti melakukan kesalahan yang melanggar kode atika profesi advokat. Meskipun dengan mutlaknya dia tidak dapat sepenuhnya baik itu berupa pidana atau perdata yang sesuai dengan perundang-undanganya.

\section{Pertanggungjawaban pidana terhadap seseorang dalam pencemaran nama baik.}

Suatu pertanggung jawaban pidana sendiri dapat terjadi karena adanya suatu tindakan pidana, baik itu dilakukan dengan kesalah berupa sengaja atau kelalaian. Seperti juga yang terjadi pada masyarakat jika seseorang terbukti besalah mereka juga haru mertanggung jawaban tidak pidana. Dalam Kitab Undang-Undang Pidana Indonesia seseorang yang dapat dipidana tidak cukup apabila orang tersebut telah melakukan perbuatan yang bertentangan dengan hukum atau bersifat melawan hukum, akan tetapi dalam penjatuhan pidana orang tersebut juga harus memenuhi syarat "Bahwa orang yang melakukan perbuatan itu mempunyai kesalahan atau bersalah. Dengan perkataan lain orang tersebut dapat dipertanggung jawabkan atas perbuatannya atau jika dilihat dari sudut perbuatannya, perbuatannya itu dapat ipertanggung jawabkan", disini berlaku asas tiada pidana tanpa kesalahan (Nulla poena sine culpa).

\section{Kesimpulan}

1. Dalam pasal 310-315 Kitab Undang-Undang Hukum Pidana yang didalamnya menyangkut tentang pencemaran nama baik. Sedangkan menurut UU ITE, pencemaran nama baik sebagaimana yang dimaksud dalam Pasal 27 ayat 
(3). pencemaran nama baik adalah setiap orang dengan sengaja dan tanpa hak mendistribusikan dan/atau mentransmisikan dan/atau membuat dapat diaksesnya informasi elektronik yang memiliki muatan penghinaan atau pencemaran nama baik. Pencemaran nama baik yang di lakukan oleh advokat sendiri,ia bebas untuk mengexplorkan peryataan di persidangan pengadilan dalam membela kasus perkara klienye yang sesuai dengan kode etikanya.

2. Pertanggungjawaban pidana terhadap advokat dalam mendampingi klien. Advokat diperbolehkan mendampingi kilennya yang menjadi terperikasa, namun ada rambu-rambu yang harus di taati. Pertangungjawaban pidana kesalahan terbesarnya sendiri sudah di atur dalam Pasal 16 UU No. 18/2003 tentang Advokat, hak imunitas advokat.

\section{Daftar Bacaan}

\section{Buku}

Oemar Seno Adji, Perkembangan Delik Pers di Indonesia (Erlangga 1999). -, Mass Media dan Hukum, cet 2. (Erlangga 1997).

Peter Mahmud Marzuki, Penelitian Hukum (Kencana 2005).

Moeljantno, Asas-Asas Hukum Pidana (Rineka Capita 2015) , Kitab Undang-Undang Hukum Pidana (Bumi Aksara 2007)

Muhammad Nuh. Etika Profesi Hukum (CV. Pustaka Setia 2011).

Roeslan Saleh, Pikiran-pikiran Tentang Pertanggungjawaban Pidana (Ghalia Indonesia 1982)

----------------, Perbuatan Pidana dan Pertanggungjawaban Pidana; Dua Pengertian Dasar dalam Hukum Pidana (Ghalia Indonesia 1980)

R. Soesilo, Kitab Undang-Undang Hukum Pidana (KUHP) Serta KomentarKomentarnya Lengkap Pasal Demi Pasal (Politeia 1995).

Dwija Priyatno, Kebijakan Legislatif tentang Sistem Pertanggungjawaban Korporasi di Indonesia (Utomo 2004). 
Didik Endro Purwoleksono, Hukum Pidana (Airlangga University Press 2013).

Theodorus Yosep Parera, Advokat Dan Penegak Hukum (Genta press 2016).

Andi Zainal Abidin, Hukum Pidana I (Sinar Grafika 1993).

\section{Jurnal}

Galih Ian, R., Tinjauan Atas pemberitaan yang Berindikasi Adanya Delik Pencemaran Nama Baik Oleh Media Massa dalam Perpektif Kode Etika Jurnalistik dan UU Pers,(2009) vol 1 Jurnal univeritas jember.

\section{Laman}

R, Galih Ian. 2009 “Tinjauan Atas Pemberitaan yang Berindikasi Adanya Delik Pencemaran Nama Baik Oleh Media Massa dalam Perspektif Kode Etik Jurnalistik Dan UU Pers". Jurnal Tugas akhir Mahasiswa. Di akses 20 Februari 2017.

Tian. Nugroho. 2010. "melawan-pers-dengan-delik-pencemaran-nama-baik". http://www.romeltea.com/2010/01/0. diakses pada hari Selasa 20 Februari 2017.

Robbani , Verdy Burhanuddin. 2016 "Analisis Yuridis Pertanggungjawaban Wartawan Atas Aduan Pencemaran Nama Baik". Jurnal Tugas akhir Mahasiswa. Diakses 25 Februari 2017.

HOW TO CITE: Mohamad Adnan Fanani, 'Delik Pencemaran Nama Baik Yang Dilakukan Oleh Advokat Dalam Melaksanakan Tugasnya Sebagai Kuasa Klien' (2018) Vol. 1 No. 3 Media Iuris. 